\title{
1 Delta Variant SARS-CoV-2 infections in pediatric cases during the second wave in India
}

$2 \quad{ }^{1 * \#}$ Pragya D. Yadav, ${ }^{2 \#}$ Gunjan Kumar, ${ }^{2 \#}$ Aparna Mukherjee, ${ }^{1}$ Dimpal A. Nyayanit, ${ }^{1}$ Anita M.

3 Shete, ${ }^{1}$ Rima R. Sahay, ${ }^{1}$ Abhinendra Kumar, ${ }^{1}$ Triparna Majumdar, ${ }^{1}$ Savita Patil, ${ }^{1}$ Priyanka

4 Pandit, ${ }^{1}$ Yash Joshi, ${ }^{1}$ Manisha Dudhmal, ${ }^{2}$ Samiran Panda, ${ }^{2}$ Lokesh Kumar Sharma, ${ }^{3 \$}$ Kala Yadav

5 ML, ${ }^{4 \$}$ Jayanthi Shastri, ${ }^{5 \$}$ Mayank Gangwar, ${ }^{6 \$}$ Ashok Munivenkattapa, ${ }^{1}$ Varsha Potdar, ${ }^{7 \$} \mathrm{~K}$

6 Nagamani, ${ }^{8 \$}$ Kapil Goyal, ${ }^{9 \$}$ Ravisekhar Gadepalli, ${ }^{10 \$}$ Maria Thomas, ${ }^{11 \$}$ Suruchi Shukla, ${ }^{12 \$} \mathrm{P}$

7 Nagraj, ${ }^{13 \$}$ Vivek Gupta, ${ }^{14 \$}$ Gaurav Dalela, ${ }^{15 \$}$ Nawaz Umar, ${ }^{16 \$}$ Sweety M Patel

$8 \quad$ \#- equal first author

$9 \quad \$$ - All authors have contributed equally

$10{ }^{1}$ Indian Council of Medical Research-National Institute of Virology, Pune, India, Pin-411021

112 Indian Council of Medical Research, V. Ramalingaswami Bhawan, Ansari Nagar, New Delhi, 12 India Pin-110029

$13 \quad{ }^{3}$ Bowring and lady Curzon Medical College, Bangalore, Karnataka Pin-560001

$14{ }^{4}$ Kasturba Hospital of Infectious diseases, Mumbai, Maharashtra Pin- 400011

$15{ }^{5}$ Institute of Medical Sciences, Banaras Hindu University, Varanasi, Uttar Pradesh Pin- 221005

$16{ }^{6}$ Indian Council of Medical Research-National Institute of Virology, Bangalore Unit Pin- 560029

$17 \quad{ }^{7}$ Gandhi Hospital, Secunderabad, Telangana Pin- 500003

$18{ }^{8}$ Postgraduate Institute of Medical Education \& research, Chandigarh Pin-160012

$19{ }^{9}$ All India Institute of Medical Sciences, Jodhpur, Rajasthan Pin- 342001 
medRxiv preprint doi: https://doi.org/10.1101/2021.12.09.21266954; this version posted December 11, 2021. The copyright holder for this preprint (which was not certified by peer review) is the author/funder, who has granted medRxiv a license to display the preprint in perpetuity. It is made available under a CC-BY-NC-ND 4.0 International license .

${ }^{10}$ Christian Medical College, Ludhiana, Punjab Pin- 141008

$21 \quad{ }^{11}$ King George Medical University, Lucknow, Uttar Pradesh Pin- 226003

$22 \quad{ }^{12}$ Gandhi Medical College, Bhopal, Madhya Pradesh Pin-462001

$23{ }^{13}$ Government Institute of Medical Sciences, Noida, Uttar Pradesh Pin- 201310

$24{ }^{14}$ Sawai Man Singh Medical College, Jaipur, Rajasthan Pin- 302004

$25{ }^{15}$ Gulbarga Institute of Medical Sciences, Rajiv Gandhi University of Health Sciences Gulbarga, 26 Karnataka, Pin-585 105

$27{ }^{16}$ Smt. NHL Municipal Medical College, Ahmedabad, Gujarat, India Pin-380006

28 *Correspondence: Maximum Containment Laboratory, Indian Council of Medical Research29 National Institute of Virology, Sus Road, Pashan, Pune 411021, India Phone: +912030 26006390/290 E-mail: hellopragya22@gmail.com

\section{Abstract}

32 The aim of this study was to identify the SARS-CoV-2 lineages circulating in the pediatric 33 population of India during the second wave of the pandemic. Clinical and demographic details 34 linked with the nasopharyngeal/oropharyngeal swabs (NPS/OPS) collected from SARS-CoV-2 35 cases $(n=583)$ aged 0 -18 year and tested positive by real-time RT-PCR were retrieved from 36 March to June 2021.Symptoms were reported among 37.2\% of patients and $14.8 \%$ reported to be 37 hospitalized. The E gene CT value had significant statistical difference at the point of sample 38 collection when compared to that observed in the sequencing laboratory. Out of these 512 39 sequences 372 were VOCs, 51 were VOIs. Most common lineages observed were Delta, 
medRxiv preprint doi: https://doi.org/10.1101/2021.12.09.21266954; this version posted December 11, 2021. The copyright holder for this preprint (which was not certified by peer review) is the author/funder, who has granted medRxiv a license to display the preprint in perpetuity. It is made available under a CC-BY-NC-ND 4.0 International license.

40 followed by Kappa, Alpha and B.1.36, seen in $65.82 \%, 9.96 \%, 6.83 \%$ and $4.68 \%$, respectively in

41 the study population. Overall, it was observed that Delta strain was the leading cause of SARS-

42 CoV-2 infection in Indian children during the second wave of the pandemic. We emphasize on

43 the need of continuous genomic surveillance in SARS-CoV-2 infection even amongst children.

44 Keywords: SARS-CoV-2, COVID-19, Delta variant, India, Pediatric 
medRxiv preprint doi: https://doi.org/10.1101/2021.12.09.21266954; this version posted December 11, 2021. The copyright holder for this preprint (which was not certified by peer review) is the author/funder, who has granted medRxiv a license to display the preprint in perpetuity.

It is made available under a CC-BY-NC-ND 4.0 International license.

45

46

47

48

49

50

51

52

\section{Introduction}

The first case of the severe acute respiratory syndrome coronavirus -2 (SARS-CoV-2) was reported from Wuhan, China during December 2019 (1). In India, the first wave of the SARSCoV-2 pandemic started in March 2020, which peaked in mid-September 2020 infecting approximately 5.7 million population(2). The predominant SARS-CoV-2 variant leading to coronavirus infection-19 (COVID-19) had a D614G mutation in the spike protein as compared to the parent strain, reported from Wuhan, China. The D614G mutation at the spike protein region was reported to have increased transmissibility (3).

Newer variants of SARS-CoV-2, having amino acid mutation in the spike protein, were reported from different countries from December 2020 that had increased ability for transmission and evasion of human immune response in comparison to earlier strains. The 20I/S: 501Y.V1 (currently alpha variant; Pango lineage: B.1.1.7) was the earliest to be reported from United Kingdom (UK) during December 2020 (4). Emergence of variants with mutations across different genes in the SARS-CoV-2 genome led to outbreaks in different countries similar to UK. The Center for Disease Control and Prevention, USA (CDC) classified the virus based on transmissibility, virulence and diagnostic availability in three classes; a) variant of concern (VOC), b) variant of interest (VOI) and c) variant of high consequences (5). The rise in the SARS-CoV-2 variants led to the development of Phylogenetic Assignment of Named Global Outbreak LINeages (PANGOLIN) classification, which is currently being used for identification of new SARS-Cov-2 variants. The World Health Organization (WHO) has labeled these variants using the Greek alphabets (alpha, beta, gamma, delta and so on) based on their reporting dates (6). Till date SARS-CoV-2 variants circulating in India were reported belonging to the pangolin 
medRxiv preprint doi: https://doi.org/10.1101/2021.12.09.21266954; this version posted December 11, 2021. The copyright holder for this preprint (which was not certified by peer review) is the author/funder, who has granted medRxiv a license to display the preprint in perpetuity.

It is made available under a CC-BY-NC-ND 4.0 International license .

67 lineage of B.1.1.7 (Alpha), B.1.351 (Beta) and B.1.1.28.1 (Gamma), B.1.1.28.2 (Zeta), B.1.617.1

68 (Kappa), B.1.617.2 (Delta) and Delta derivatives as well as B.1.617.3 (7-9).

There is limited information pertaining to the SARS-CoV-2 strain infecting the children

70

71

72

73

74

76

77

78

79

80

81

82

83

84

The current study was performed to identify the SARS-CoV-2 lineages circulating in the pediatric population across 8 States and one Union Territory in India during the second wave of the pandemic during March to June which attained its peak in May 2021. Additionally, the Indian pediatric SARS-CoV-2 sequences available with GISAID database with collection date from January 2020 to July 31, 2021were also analyzed.

\section{Materials and Methods}

\section{Study Sites and retrieval of the clinical data}

The National Clinical Registry for COVID-19 is a data collection platform for hospitalized COVID-19 patients maintained by the Indian Council of Medical Research (ICMR) in collaboration with the Ministry of Health \& Family Welfare (MOHFW), All India Institute of Medical Sciences (AIIMS), New Delhi and ICMR-National Institute of Medical Statistics (NIMS). The structure and protocol of the registry are available in the public domain. (https://www.icmr. gov.in/tablar1.html). Currently, forty one tertiary care hospitals, both public and private, across India, are involved in this registry. All participating hospitals were invited to 
medRxiv preprint doi: https://doi.org/10.1101/2021.12.09.21266954; this version posted December 11, 2021. The copyright holder for this preprint (which was not certified by peer review) is the author/funder, who has granted medRxiv a license to display the preprint in perpetuity.

It is made available under a CC-BY-NC-ND 4.0 International license .

89 send stored nasopharyngeal samples of COVID-19 positive children aged 0-18 year. Twelve

90 participating institutes and in addition two VRDL laboratories agreed to send samples. These

91 collections were carried out by designated laboratories. Clinical and demographic details of

92 SARS-CoV-2 cases $(\mathrm{n}=583)$ aged 0 -18 year, tested positive by real-time RT-PCR were retrieved

93 using the central testing database from ICMR. The samples collected had representation from 8

94 States and one Union Territory (Chandigarh), and were collected during a period of March 2020

95 to June 2021. (Maharashtra, Gujarat, Uttar Pradesh, Karnataka, Rajasthan, Madhya Pradesh,

96 Punjab and Andhra Pradesh) (www.icmr.gov.in).

\section{Inclusion, exclusion criteria and transport of specimens}

SARS-CoV-2 cases fulfilling the following inclusion criteria were enrolled under the study: i)

99 Nasopharyngeal/Oropharyngeal (NPS/OPS) swab samples collected fromSARS-CoV-2 cases

during the period of second wave ii) Cases whose real time RT-PCR threshold value was $<30$

and NPS/OPS were appropriately stored at $-80{ }^{\circ} \mathrm{C}$; (iii) Sample referral forms (SRF) capturing

Provision of the consent from the parents/guardians. The NPS/OPS samples of all these cases

which fulfilled all the inclusion criteria were packed in triple-layer packaging with dry ice as per sequencing (NGS) and variant analysis.

\section{RNA extraction and NGS on the clinical samples}


medRxiv preprint doi: https://doi.org/10.1101/2021.12.09.21266954; this version posted December 11, 2021. The copyright holder for this preprint (which was not certified by peer review) is the author/funder, who has granted medRxiv a license to display the preprint in perpetuity.

It is made available under a CC-BY-NC-ND 4.0 International license.

111 time RT PCR. For preparation of RNA libraries Illumina CovidSeq protocol (Illumina Inc, USA)

112 was followed (12). In brief, the first strand synthesized from extracted RNA was amplified using

113 two primers pools followed by tagmentation. This tagmented amplicon was further used for the

114 preparation of libraries as per manufacturer's instructions. The libraries were pooled, purified,

115 quantified and then loaded at final loading concentration of 1.4picomole onto the NextSeq

116 500/550 system using NextSeq 500/550 High Output Kit v2.5 (75 Cycles) (Illumina Inc).

The paired-end FASTQ files generated were analyzed on the CLC Genomics Workbench

version 21.0.4 (CLC, Qiagen). Wuhan Hu-1 isolate (Accession Number: NC_045512.2) was

used for reference based assembly to retrieve the genomic sequence of the SARS-CoV-2. The

retrieved sequences were deposited in the public repository of Global Initiative on Sharing Avian

121 Influenza Data (GISAID) database to make the data available for others. were used in the analysis along with the sequences retrieved in this study. The sequences were

127 aligned using the CLC genomics workbench. The aligned file was manually checked for 128 correctness. A neighbor-joining phylogenetic tree was constructed from the coding region of the 129 SARS-CoV-2 genome using the maximum composite likelihood model along with gamma 130 distribution as the rate variation parameter. A bootstrap replication of 1000 cycles was performed 131 to assess the statistical robustness of the generated tree. The amino acid variation for each gene 
medRxiv preprint doi: https://doi.org/10.1101/2021.12.09.21266954; this version posted December 11, 2021. The copyright holder for this preprint (which was not certified by peer review) is the author/funder, who has granted medRxiv a license to display the preprint in perpetuity.

It is made available under a CC-BY-NC-ND 4.0 International license .

132 and net nucleotide and amino acid divergence was identified using the MEGA software version

$1337.0(14)$ and illustrated using GraphPad Prism v9.

\section{Statistical Analysis}

Data analysis was done using STATA v14 (College Station, TX). The continuous variables were described as mean with standard deviation (SD) or median with inter quartile

137 range (IQR). The categorical variables were described as frequency and proportions. Association

138 between categorical variables was tested by applying chi square test. Difference amongst the 139 continuous variables was tested using paired and unpaired student's t-test or ANOVA as 140 required. $\mathrm{P}$ value less than 0.05 was considered to be significant at $95 \%$ confidence interval (CI).

141 Results

\section{Clinico-demographic analysis}

143 We present here the results of 583 samples included in the current study. Table 1 shows the 144 demographic and clinical characteristics of the enrolled children at baseline. More than half the 145 samples were from males and the median (IQR) age of the study participants was 13 year (8, 16).More than half of the patients $(51.8 \%)$ belonged to the age group of $13-19$ year, $41.2 \%$ to 3 -

14712 year and the rest $7 \%$ to less than 3 year. Symptoms were reported among $37.2 \%$ of patients 148 and $14.8 \%$ reported to be hospitalized. Symptom profile was available for only 74 patients, with 149 fever, cough, runny nose and sore throat, being the most common symptoms noted in $60 \%$, $15049.3 \%, 23.4 \%$ and $12 \%$ of the children, respectively. The rest of the symptoms were seen in less 151 than $10 \%$ of the patients. Significant statistical difference was observed in the E gene CT value 152 at the point of sample collection and at ICMR-NIV, Pune, with that being done at ICMR-NIV to 153 be lower. The CT values were not significantly different among the lineages, among males and 
medRxiv preprint doi: https://doi.org/10.1101/2021.12.09.21266954; this version posted December 11, 2021. The copyright holder for this preprint (which was not certified by peer review) is the author/funder, who has granted medRxiv a license to display the preprint in perpetuity.

It is made available under a CC-BY-NC-ND 4.0 International license .

154 females, different age groups, hospitalized and non-hospitalized patients, though it was

155 significantly lower among symptomatic and hospitalized patients [Table-2].

156

157

158

159

160

161

162

163

164

165

166

167

168

\section{SARS-CoV-2 data analysis, NGS and phylogenetic analysis}

In order to understand the dominance of SARS-CoV-2 variant present during the first wave of its outbreak, the 1751 pediatric SARS-CoV-2 sequences were grouped into two based on the presence of $\mathrm{D} 614 \mathrm{G}$ mutation in the spike region. The month-wise observation of the groups is depicted in Figure-1. Month-wise cases reported without D614G mutations revealed the presence of early GISAID clades (L, S, and V) (Figure-1A). The predominance of these variants was observed till August 2020 in pediatric sequences (Figure-1A). The first SARS-CoV2 to be reported belonged to unclassified cluster ('O') with few cases of the other clades [L, S, and V]. Month-wise cases reported with D614G mutation ('G' clade) is depicted in Fig 1B.TheG clade variant of SARS-CoV-2 was reported as early as March 2020. This variant along with its sister clades predominated until February 2021, the first wave of SARS-CoV-2 in India. The amino acid changes observed with the sister clades are GH(S: D614G, NS3: Q57H; Greek name: Beta) and GR(S: D614G, N: G204R; Greek name: Gamma).

As observed in the adult population, the new SARS-CoV-2 variants were also reported in the pediatric cases from India. These variants were GK(S-D614G + S-T478K; Greek name: Delta), GRY (S-H69del, S-V70del, S-Y144del, S-N501Y + S-D614G + N-G204R; Greek name: Alpha) and GV(S-D614G + S-A222V). The GRY variant was the first to be reported, beginning from November 2020 followed by the GK variant from December 2020. The reporting of these variants increased rapidly during the consequent months. They superseded earlier GR (Gamma) and GH (Beta) variant of SARS-CoV-2 during March 2021 which also marks the beginning of 
medRxiv preprint doi: https://doi.org/10.1101/2021.12.09.21266954; this version posted December 11, 2021. The copyright holder for this preprint (which was not certified by peer review) is the author/funder, who has granted medRxiv a license to display the preprint in perpetuity.

It is made available under a CC-BY-NC-ND 4.0 International license.

176

177

178

179

180

181

182

183

184

185

186

187

188

189

190

191

192

193

194

195

196

SARS-CoV-2's second wave in India (Figure-1B).The B.1.617.2 (Delta) variant showed a steep rise after March 2021, reaching to 100\% amongst the collected samples in June. (Figure-1B).

Out of the 583 samples that were used for NGS, SARS-CoV-2 sequences with $98.5 \%$ genome coverage were retrieved from 512 samples. The details of the percent genome coverage, relevant read mapped and the total reads for each sample along with their EPI-Accession numbers are given in Supplementary Table-S1. These sequences were classified into PANGOLIN lineage using https://pangolin.cog-uk.io/. The PANGOIN lineage of the SARSCoV-2 sequences is also given in Supplementary Table 1. Out of these 512 sequences 372 were VOCs, 51 were VOIs and 89 were the other reported variants. Most common lineages observed were Delta, followed by Kappa, Alpha and B.1.36, seen in 65.82\%, 9.96\%, 6.83\% and 4.68\%, respectively in the study group.

Out of 1752 SARS-CoV-2 sequences from pediatric age group, 1609 sequences were used for further analysis based on the complete genome coverage and high-quality reads. A total of 2121 SARS-CoV-2 sequences [comprising of 1609 sequences from GISAID database and 512 SARS-CoV-2 sequences retrieved from this study] were analyzed further. It was observed that the Kappa was first reported in the pediatric case as early as September 2020 followed by Delta during October 2020 (Figure-2A). It is notable that no VOCs and VOIs were reported in the pediatric population prior to September 2020. The Alpha variant was reported later to Kappa from December 2020, which is reversed in case of adult population.

During January-March of 2021, a higher number of Alpha variant cases were reported, which was superseded rapidly by Delta (Figure-2A) amongst children. The Delta variant is 
medRxiv preprint doi: https://doi.org/10.1101/2021.12.09.21266954; this version posted December 11, 2021. The copyright holder for this preprint (which was not certified by peer review) is the author/funder, who has granted medRxiv a license to display the preprint in perpetuity. It is made available under a CC-BY-NC-ND 4.0 International license .

197 currently also the most predominant strain circulating amongst pediatric population. Along with 198 these a few other VOCs and VOIs were also reported (Figure-2B).

199 The lineage distribution of the 512 SARS-CoV-2 sequences retrieved across the different 200 states studied is depicted in Figure-3. It was observed that Delta lineage predominated in 201 Karnataka, Uttar Pradesh, Madhya Pradesh and Telangana whereas the Kappa variant was 202 observed in Maharashtra, Rajasthan and Chandigarh. The northern part of India revealed the 203 presence of SARS-CoV-2 strains apart from the VOC and VUIs. Overall, it was observed that 204 Delta strain predominated as the leading cause to SARS-CoV-2 infection in children in India 205 during the second wave of the pandemic.

The maximum likelihood tree was generated using the GTR+G as substitution model and 207 a bootstrap replication of 1000 cycles. A separate cluster of B.1.617 lineage was observed that 208 segregated into Kappa, Delta and B.1.617.3 lineages as depicted in Figure 4. 
medRxiv preprint doi: https://doi.org/10.1101/2021.12.09.21266954; this version posted December 11, 2021. The copyright holder for this preprint (which was not certified by peer review) is the author/funder, who has granted medRxiv a license to display the preprint in perpetuity.

It is made available under a CC-BY-NC-ND 4.0 International license .

209

\section{Discussion}

India after the completion of massive immunization of 1 billion doses of COVID-19 in the adult population has recently approved two vaccines for pediatric use namely Covaxin/BBV152 (inactivated virus vaccine) and ZyCoV-D (DNA vaccine), both vaccines are being manufactured in India. Advocacy for re-opening of schools based on evidence was ongoing (15) and many states have started taking cognizance of the same. The plausibility of a third wave in India has also been extensively studied and helped programmatic discussion and decision making(16). Studies underline that children aged 1-17 year are susceptible to a milder form of COVID-19 but not to severe disease in comparison to the adult population (17). The reasons behind this were mainly the lower density of angiotensin-converting enzyme-2 (ACE2) receptors lining the respiratory tract (17). The 4th serosurvey of COVID-19 in India showed that more than $50 \%$ children belonging to 6-17 year age group were seropositive emphasizing that a huge number of children were infected as adults $(18,19)$, but not many of them required institutional care.

Genome sequencing of SARS-CoV-2 has played an important role in determining its emerging variants, geographical predominance, evolution over different times and understanding its trend. In India during the first wave of SARS-CoV-2 the variant with spike protein D614G mutation had dominated. The epidemiological SARS-CoV-2 analysis of adult population from India demonstrated the GH and GR clades to predominate in the northern and southern part of India respectively $(20,21)$. The current study is a molecular epidemiology study which explored the SARS-CoV-2 distribution in the pediatric cases from different parts of India during the first and second wave of pandemic. It was observed that the majority of the pediatric cases reported during the first wave did not have the spike protein D614G mutation and later B.1.617 lineage 
232

233

234

235

was found to be predominant in children as observed in adult SARS-CoV-2 infections(20). Further the four derivatives of Delta were also observed in the pediatric sequences as described earlier (22,23). It was observed that sub-lineage I had majority of the Delta lineage shared followed by sub lineage-II (Figure-4).

The second wave of the COVID-19 in the world witnessed the emergence of variants of concern (Alpha, Beta, Gamma, Delta) and VOIs (Kappa, Zeta, Lambda (C.37)] in the adults. In India, the first pediatric case infected with Alpha strain was reported in November 2020.Further an increase in the number of cases was observed with Alpha and the Delta variants. It was observed that majority of the pediatric cases across the states surveyed in the current study had Delta variant indicating it to be a predominant strain with amino acid changes in ORF1ab (A1306S, P2046L, P2287S, V2930L, T3255I, T3446A, G5063S, P5401L, A6319V) and N G215C.This study identifies the SARS-CoV-2 variant responsible for the infection in the pediatric population and highlights the importance of genomic surveillance in children.

\section{Author Contributions:}

Conception and design of study: P D. Yadav, A Mukherjee, S Panda Acquisition of data (laboratory or clinical): P D. Yadav, S Panda, G Kumar, AMukherjee, K Yadav ML, J Shastri, M Gangwar, A Munivenkattapa, V Potdar, K Nagamani, K Goyal, R Gadepalli, M Thomas, S Shukla, Nagraj, V Gupta, G Dalela, N Umar, S M Patel, L K Sharma, R R. Sahay, A Kumar, D A. Nyayanit, A M. Shete, S Patil, T Majumdar, M Dudhmal, P Pandit and Y Joshi Data analysis and/or interpretation: P D. Yadav, D A. Nyayanit, G Kumar, A Mukherjee Drafting of manuscript and/or critical revision: P D. Yadav, G Kumar, D A. Nyayanit, A Mukherjee Approval of final version of manuscript: P D. Yadav, A Mukherjee, S Panda, G Kumar, K Yadav ML, J Shastri, M Gangwar, A Munivenkattapa, V Potdar, K Nagamani, K Goyal, R Gadepalli, M Thomas, S Shukla, Nagraj, V Gupta, G Dalela, N Umar, S M Patel, L K Sharma, R R. Sahay, A Kumar, D A. Nyayanit, A M. Shete, S Patil, T Majumdar, M Dudhmal, P Pandit and Y Joshi 
medRxiv preprint doi: https://doi.org/10.1101/2021.12.09.21266954; this version posted December 11, 2021. The copyright holder for this preprint (which was not certified by peer review) is the author/funder, who has granted medRxiv a license to display the preprint in perpetuity.

It is made available under a CC-BY-NC-ND 4.0 International license .

258 Funding: The study was conducted with intramural funding for 'Molecular epidemiological 259 analysis of SARS-CoV-2 is circulating in different regions of India' of Indian Council of 260 Medical Research (ICMR), New Delhi, provided to ICMR-National Institute of Virology, Pune.

261 Institutional Review Board Statement: The study was approved by the Institutional Human 262 Ethics Committee of ICMR-NIV, Pune, India under project 'Molecular epidemiological analysis 263 of SARS- CoV-2 circulating in different regions of India'(IHEC no. NIV/IEC/Dec/2020/D-6 264 dated 31 December 2020).

265 Informed Consent Statement: Patient consent was waived due to screening of retrospective 266 samples (TS/NS) already collected during Covid-19 pandemic by all the respective centers 267 involved in the study.

268 Data Availability Statement: All the sequencing data and information of this study is available 269 in GISAID. Accession no is provided in supplementary table.

270 Acknowledgments: Authors gratefully acknowledge the encouragement and support extended

271 by Dr. Balram Bhargava, Secretary to the Government of India, Department of Health Research, 272 Ministry of Health and Family Welfare and Director-General, ICMR and Prof. (Dr.) Priya 273 Abraham, Director, ICMR-NIV, Pune. We are grateful to Mrs. Ashwini Waghmare, Ms. Pranita 274 Gawande, Mrs. Kaumudi Kalele, Ms. Jyoti Yemul and Mrs. Tejashri Kore for excellent technical 275 support during the study. We thank to all contributors those have submitted the SARS-CoV-2 276 sequences in the GISAID database

277 Conflicts of Interest: The authors declare no conflict of interest 
medRxiv preprint doi: https://doi.org/10.1101/2021.12.09.21266954; this version posted December 11, 2021. The copyright holder for this preprint (which was not certified by peer review) is the author/funder, who has granted medRxiv a license to display the preprint in perpetuity.

It is made available under a CC-BY-NC-ND 4.0 International license.

278

279

280

281

282

283

284

285

286

287

288

289

290

291

292

293

294

295

296

297

\section{References}

1. Zhu N, Zhang D, Wang W, Li X, Yang B, Song J, et al. A Novel Coronavirus from Patients with Pneumonia in China, 2019. N Engl J Med. 2020 Feb 20;382(8):727-33.

2. India COVID: 34,386,786 Cases and 461,827 Deaths - Worldometer [Internet]. [cited 2021 Nov 10]. Available from: https://www.worldometers.info/coronavirus/country/india/

3. Hamed SM, Elkhatib WF, Khairalla AS, Noreddin AM. Global dynamics of SARS-CoV-2 clades and their relation to COVID-19 epidemiology. Sci Rep. 2021 Apr 19;11(1):8435.

4. Preliminary genomic characterisation of an emergent SARS-CoV-2 lineage in the UK defined by a novel set of spike mutations - SARS-CoV-2 coronavirus / nCoV-2019 Genomic Epidemiology [Internet]. Virological. 2020 [cited 2021 Jun 14]. Available from: https://virological.org/t/preliminary-genomic-characterisation-of-an-emergent-sars-cov-2lineage-in-the-uk-defined-by-a-novel-set-of-spike-mutations/563

5. CDC. Coronavirus Disease 2019 (COVID-19) [Internet]. Centers for Disease Control and Prevention. 2020 [cited 2021 Nov 10]. Available from: https://www.cdc.gov/coronavirus/2019-ncov/variants/variant-info.html

6. Tracking SARS-CoV-2 variants [Internet]. [cited 2021 Jun 14]. Available from: https://www.who.int/activities/tracking-SARS-CoV-2-variants

7. Yadav PD, Sapkal GN, Abraham P, Ella R, Deshpande G, Patil DY, et al. Neutralization of variant under investigation B.1.617 with sera of BBV152 vaccinees. Clin Infect Dis. 2021 May 7;ciab411. 
medRxiv preprint doi: https://doi.org/10.1101/2021.12.09.21266954; this version posted December 11, 2021. The copyright holder for this preprint (which was not certified by peer review) is the author/funder, who has granted medRxiv a license to display the preprint in perpetuity.

It is made available under a CC-BY-NC-ND 4.0 International license .

298

299

300

301

302

303

304

305

306

307

308

309

310

311

312

313

314

315

316

317

8. Yadav PD, Nyayanit DA, Sahay RR, Sarkale P, Pethani J, Patil S, et al. Isolation and characterization of the new SARS-CoV-2 variant in travellers from the United Kingdom to India: VUI-202012/01 of the B.1.1.7 lineage. J Travel Med. 2021 Feb 23;28(2):taab009.

9. Yadav PD, Gupta N, Nyayanit DA, Sahay RR, Shete AM, Majumdar T, et al. Imported SARS-CoV-2 V501Y.V2 variant (B.1.351) detected in travelers from South Africa and Tanzania to India. Travel Med Infect Dis. 2021;41:102023.

10. Ludvigsson JF. Systematic review of COVID-19 in children shows milder cases and a better prognosis than adults. Acta Paediatr. 2020 Jun;109(6):1088-95.

11. Yonker LM, Boucau J, Regan J, Choudhary MC, Burns MD, Young N, et al. Virologic features of SARS-CoV-2 infection in children. medRxiv. 2021 Aug $17 ; 2021.05 .30 .21258086$

12. Bhoyar RC, Jain A, Sehgal P, Divakar MK, Sharma D, Imran M, et al. High throughput detection and genetic epidemiology of SARS-CoV-2 using COVIDSeq next-generation sequencing. PLOS ONE. 2021 Feb 17;16(2):e0247115.

13. Shu Y, McCauley J. GISAID: Global initiative on sharing all influenza data - from vision to reality. Euro Surveill. 2017 Mar 30;22(13):30494.

14. Kumar S, Stecher G, Tamura K. MEGA7: Molecular Evolutionary Genetics Analysis Version 7.0 for Bigger Datasets. Mol Biol Evol. 2016 Jul;33(7):1870-4.

15. Anand T, Bhargava B, Panda S. Reopening of schools during COVID-19 pandemic: A persistent dilemma. Indian J Med Res. 2021 Jun;153(5 \& 6):572-6. 
medRxiv preprint doi: https://doi.org/10.1101/2021.12.09.21266954; this version posted December 11, 2021. The copyright holder for this preprint (which was not certified by peer review) is the author/funder, who has granted medRxiv a license to display the preprint in perpetuity.

It is made available under a CC-BY-NC-ND 4.0 International license.

318

319

320

321

322

323

324

325

326

327

328

329

330

331

332

16. Mandal S, Arinaminpathy N, Bhargava B, Panda S. Plausibility of a third wave of COVID19 in India: A mathematical modelling based analysis. Indian J Med Res. 2021 Jun;153(5 \& 6):522-32.

17. Zimmermann P, Curtis N. Why is COVID-19 less severe in children? A review of the proposed mechanisms underlying the age-related difference in severity of SARS-CoV-2 infections. Arch Dis Child. 2020 Dec 1;archdischild-2020-320338.

18. COVID-19 in children and the role of school settings in transmission - second update [Internet]. European Centre for Disease Prevention and Control. 2021 [cited 2021 Nov 10]. Available from: https://www.ecdc.europa.eu/en/publications-data/children-and-schoolsettings-covid-19-transmission

19. July 20 MSND, July 20 2021UPDATED:, Ist 2021 21:23. 67\% surveyed Indians have developed antibodies against coronavirus, 40 crore still at risk: Govt [Internet]. India Today. [cited 2021 Nov 10]. Available from: https://www.indiatoday.in/coronavirusoutbreak/story/fourth-serosurvey-result-67-percent-indians-developed-antibodies-againstcovid19-1830443-2021-07-20

20. Yadav PD, Nyayanit DA, Majumdar T, Patil S, Kaur H, Gupta N, et al. An Epidemiological Analysis of SARS-CoV-2 Genomic Sequences from Different Regions of India. Viruses. 2021 May 17;13(5):925.

21. Kustin T, Harel N, Finkel U, Perchik S, Harari S, Tahor M, et al. Evidence for increased breakthrough rates of SARS-CoV-2 variants of concern in BNT162b2-mRNA-vaccinated individuals. Nat Med. 2021 Aug;27(8):1379-84. 
medRxiv preprint doi: https://doi.org/10.1101/2021.12.09.21266954; this version posted December 11, 2021. The copyright holder for this preprint (which was not certified by peer review) is the author/funder, who has granted medRxiv a license to display the preprint in perpetuity. It is made available under a CC-BY-NC-ND 4.0 International license .

339 22. Gupta N, Kaur H, Yadav PD, Mukhopadhyay L, Sahay RR, Kumar A, et al. Clinical 340 Characterization and Genomic Analysis of Samples from COVID-19 Breakthrough 341 Infections during the Second Wave among the Various States of India. Viruses. 2021 Sep $342 \quad 7 ; 13(9): 1782$.

343 23. Thangaraj JWV, Yadav P, Kumar CG, Shete A, Nyayanit DA, Rani DS, et al. Predominance 344 of delta variant among the COVID-19 vaccinated and unvaccinated individuals, India, May 345 2021. J Infect [Internet]. 2021 Aug 6 [cited 2021 Nov 10]; Available from: 346 https://www.ncbi.nlm.nih.gov/pmc/articles/PMC8343391/ 
medRxiv preprint doi: https://doi.org/10.1101/2021.12.09.21266954; this version posted December 11, 2021. The copyright holder for this preprint (which was not certified by peer review) is the author/funder, who has granted medRxiv a license to display the preprint in perpetuity. It is made available under a CC-BY-NC-ND 4.0 International license .

349 Figure 1 Month wise distribution of the GISIAD clade: A month -wise distribution of

350 pangolin lineages classified under A) without D614G and B) with D614G mutation. The x-axis

351 depicts the different months in year 2020-2021 and the Y-axis is the Log2 scale of SARS-CoV-2

352 cases reported in GISAID. 
medRxiv preprint doi: https://doi.org/10.1101/2021.12.09.21266954; this version posted December 11, 2021. The copyright holder for this preprint (which was not certified by peer review) is the author/funder, who has granted medRxiv a license to display the preprint in perpetuity.

It is made available under a CC-BY-NC-ND 4.0 International license .

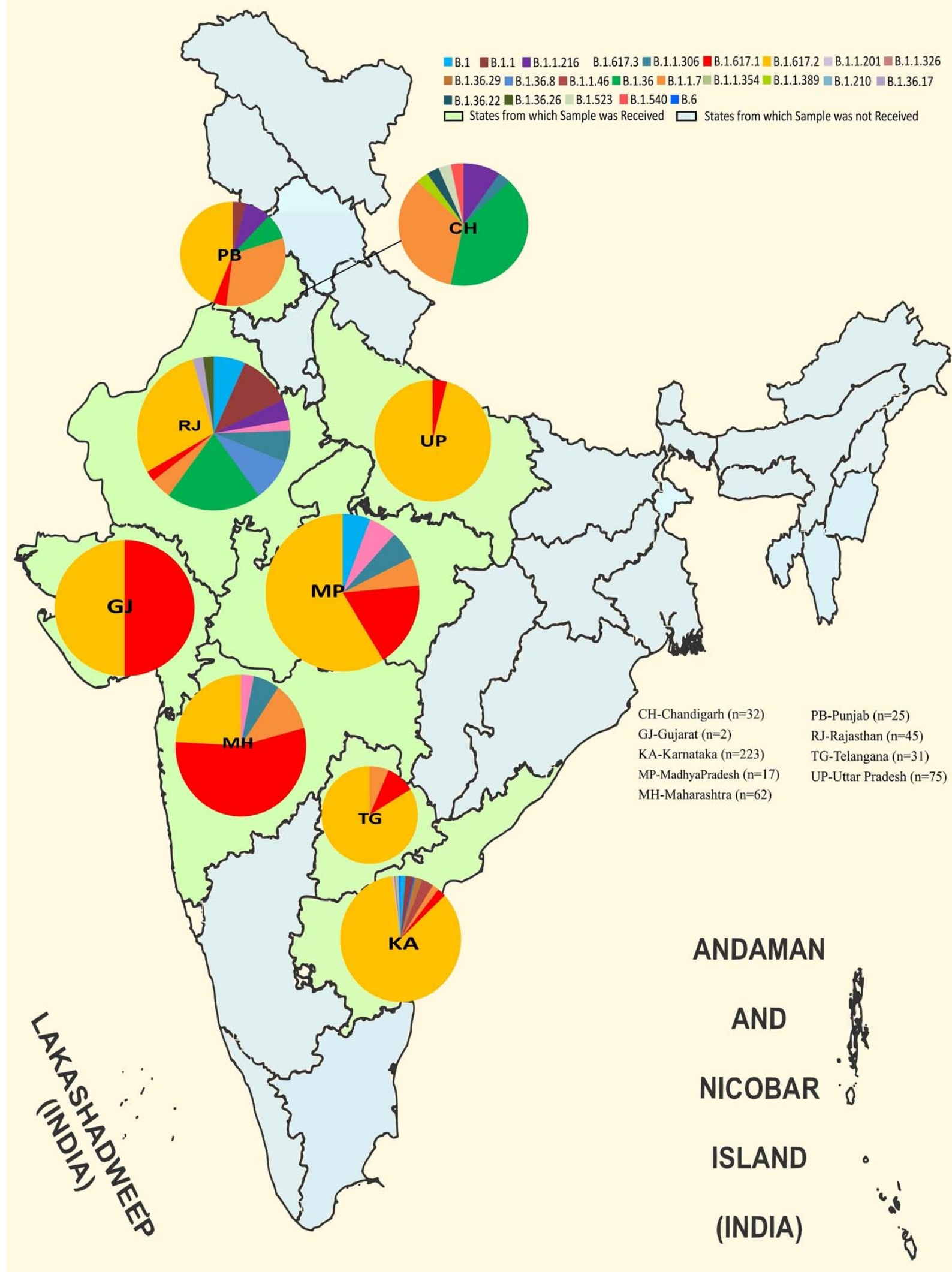


medRxiv preprint doi: https://doi.org/10.1101/2021.12.09.21266954; this version posted December 11, 2021. The copyright holder for this preprint (which was not certified by peer review) is the author/funder, who has granted medRxiv a license to display the preprint in perpetuity.

It is made available under a CC-BY-NC-ND 4.0 International license .

Figure 2 Month wise distribution of the Pangolin lineages: A month -wise distribution pangolin lineages classified under A) VOC and VOI and B) other lineages. The x-axis depicts the different months in year 2020-2021 and the Y-axis is the Log2 scale of SARS-CoV-2 cases reported in GISAID and retrieved during this study.

\section{A Month wise case reported without D614G mutation}

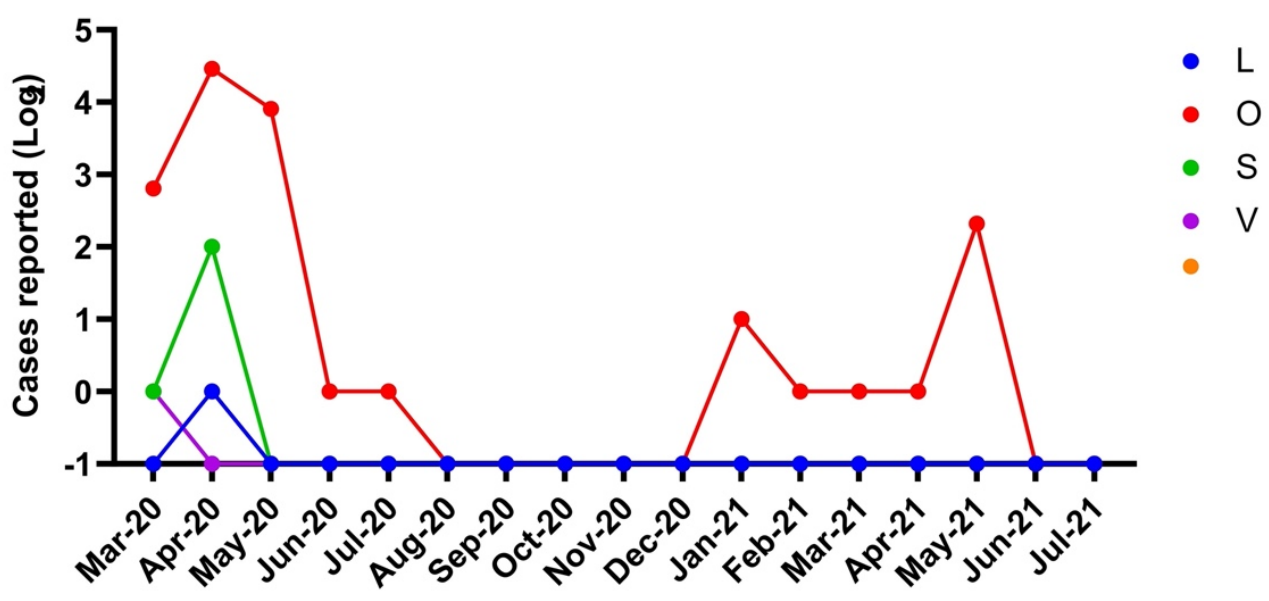

Time (months)

B Month wise case reported with D614G mutation

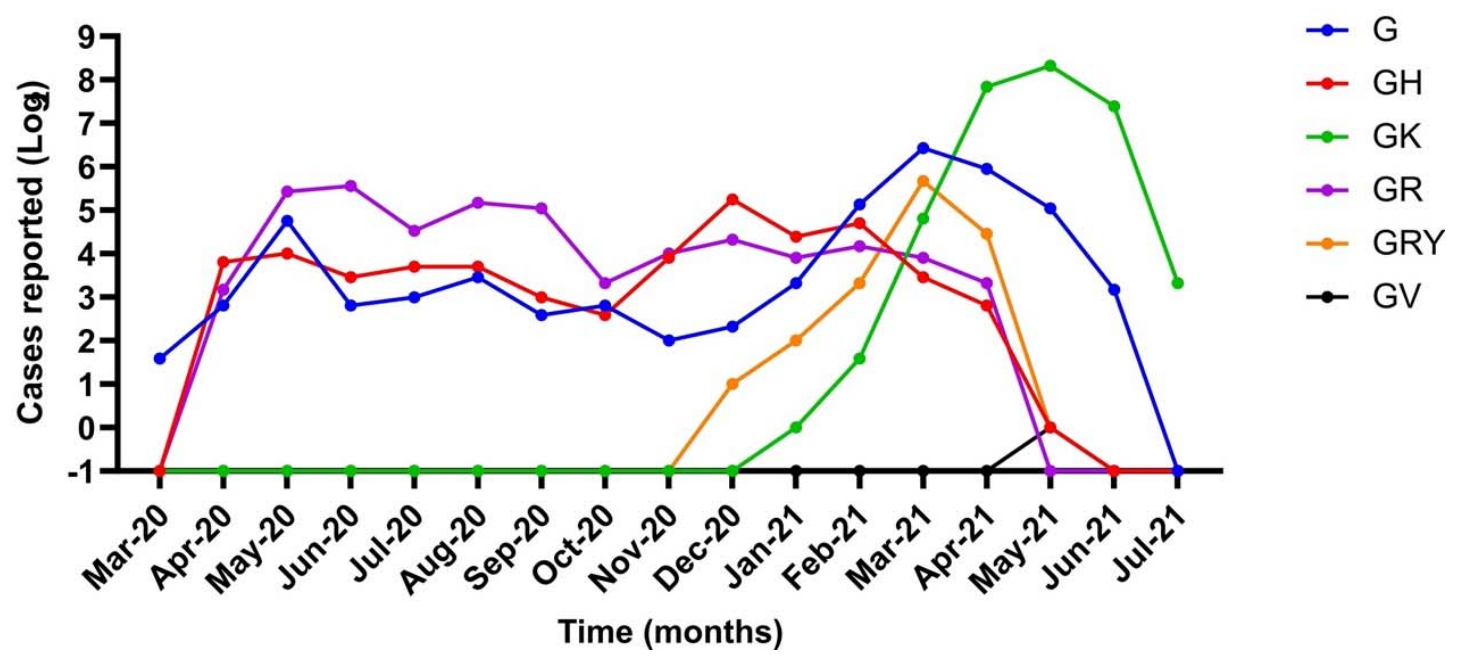


medRxiv preprint doi: https://doi.org/10.1101/2021.12.09.21266954; this version posted December 11, 2021. The copyright holder for this preprint (which was not certified by peer review) is the author/funder, who has granted medRxiv a license to display the preprint in perpetuity. It is made available under a CC-BY-NC-ND 4.0 International license.

361 Figure 3 Distribution of the SARS-CoV-2 genome prevalence among cases pediatric cases

362 in India. The distribution in the pie chart is proportional to the numbers in each respective clade

363 in each state. The outline of India's map was downloaded from

364 http://www.surveyofindia.gov.in/file/Map\%20f\%20India_1.jpg (accessed on 20 March 2020)

365 and further modified to include relevant data in the SVG editor. 
medRxiv preprint doi: https://doi.org/10.1101/2021.12.09.21266954; this version posted December 11, 2021. The copyright holder for this preprint (which was not certified by peer review) is the author/funder, who has granted medRxiv a license to display the preprint in perpetuity.

It is made available under a CC-BY-NC-ND 4.0 International license .

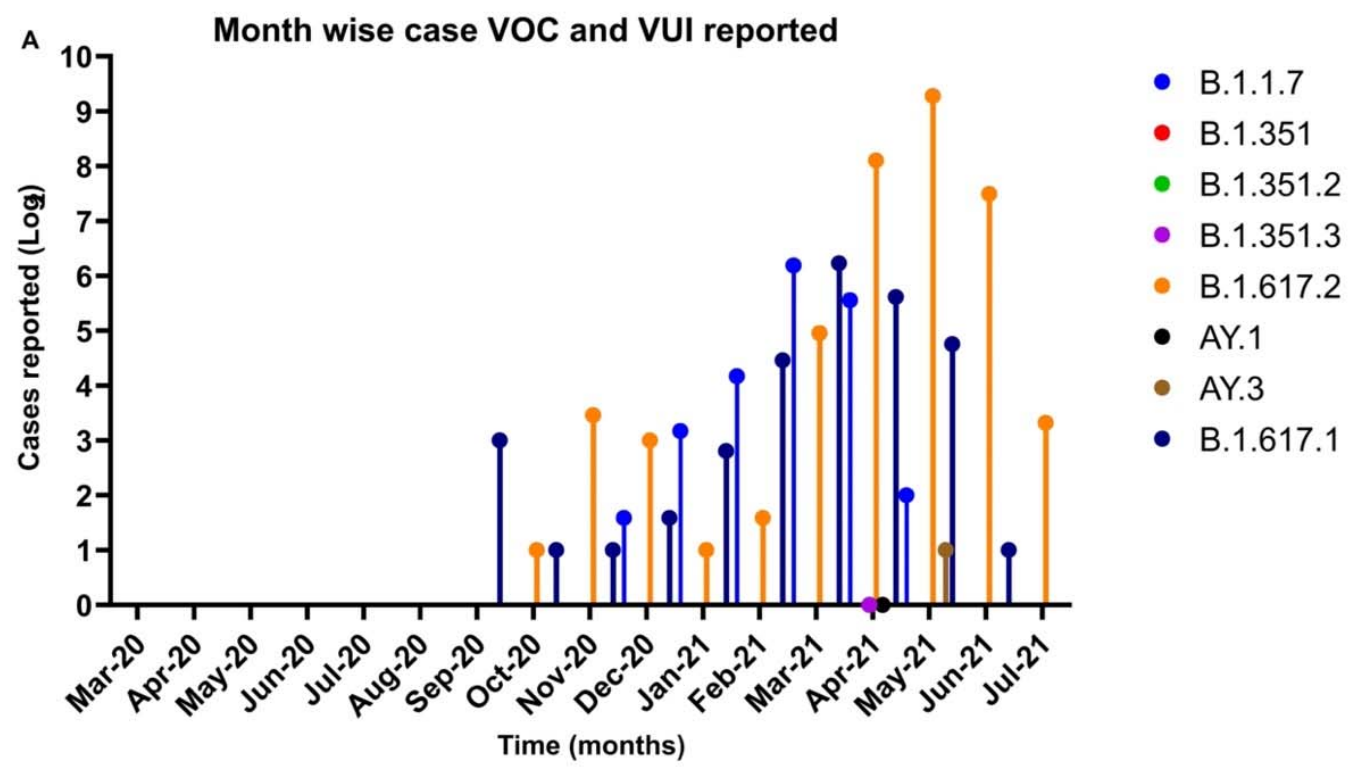

B

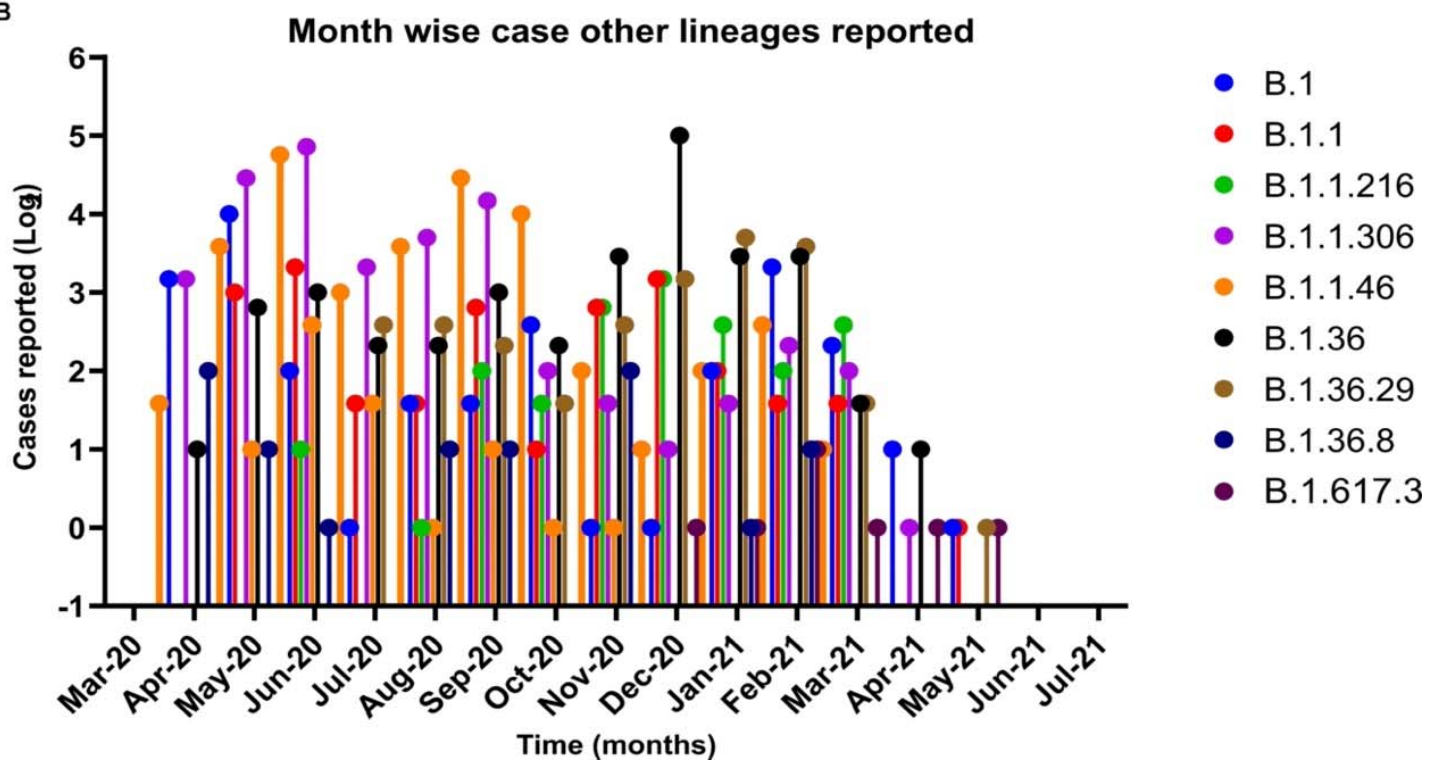


medRxiv preprint doi: https://doi.org/10.1101/2021.12.09.21266954; this version posted December 11, 2021. The copyright holder for this preprint (which was not certified by peer review) is the author/funder, who has granted medRxiv a license to display the preprint in perpetuity. It is made available under a CC-BY-NC-ND 4.0 International license .

370 Figure 4: Maximum likelihood tree for the SARS-CoV-2 genomes retrieved from pediatric

371 cases. Representative SARS-CoV-2 sequences from different lineages along with 512 sequences

372 retrieved were used to generate the tree with a bootstrap replication of 1000 cycles. The sub-

373 lineages I-IV of B.1.617.2are marked in red, green, pink, and orange color on the nodes,

374 respectively. B.1.617.1 sequence is marked in brown and B.1.617.3 in blue color. The other

375 retrieved pangolin lineages are also marked on branches in different colors. Fig Tree v1.4.4 and

376 Inkscape were used to visualize and edit the generated tree. 
medRxiv preprint doi: https://doi.org/10.1101/2021.12.09.21266954; this version posted December 11, 2021. The copyright holder for this preprint (which was not certified by peer review) is the author/funder, who has granted medRxiv a license to display the preprint in perpetuity.

It is made available under a CC-BY-NC-ND 4.0 International license .

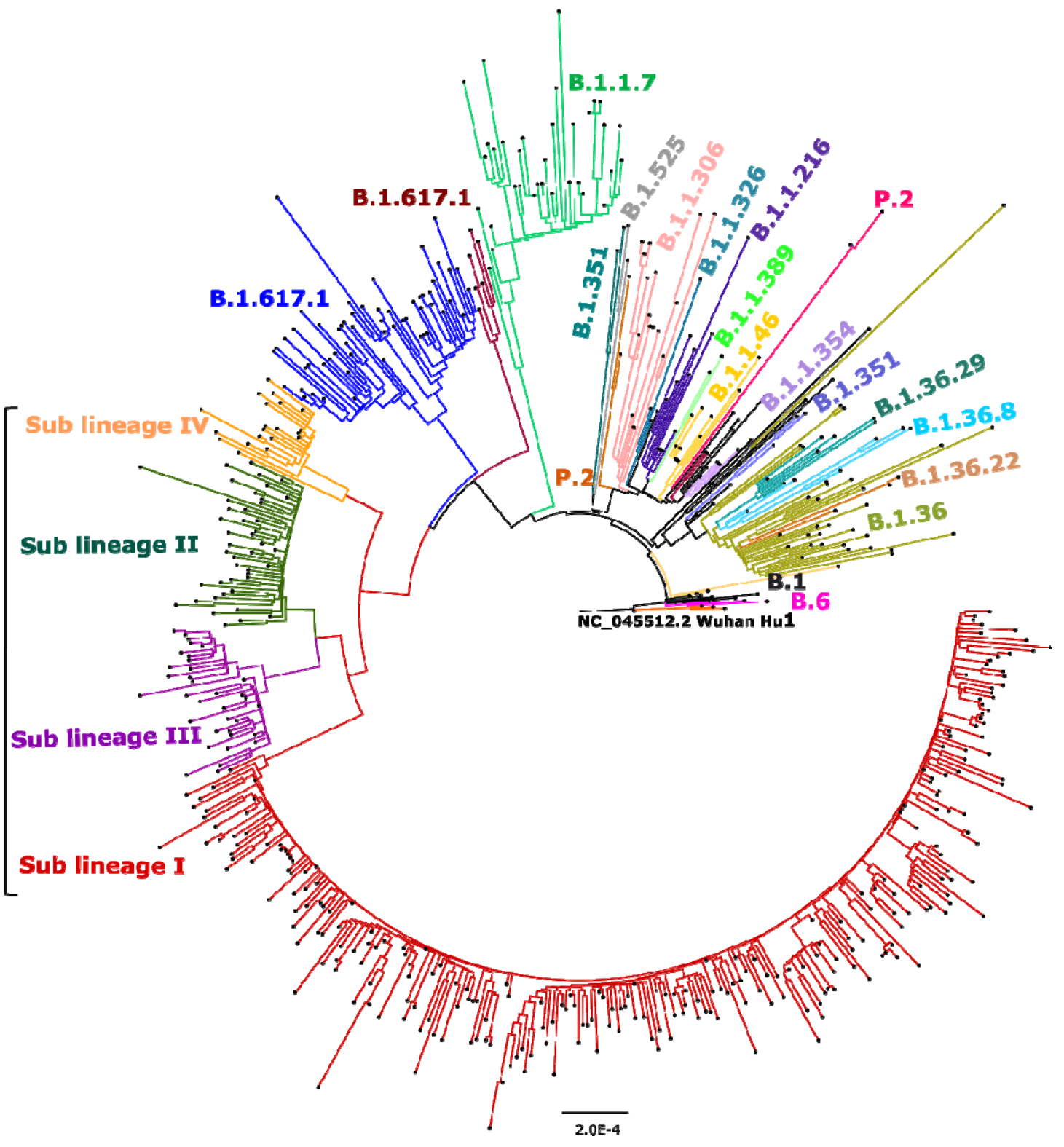


medRxiv preprint doi: https://doi.org/10.1101/2021.12.09.21266954; this version posted December 11, 2021. The copyright holder for this preprint (which was not certified by peer review) is the author/funder, who has granted medRxiv a license to display the preprint in perpetuity.

It is made available under a CC-BY-NC-ND 4.0 International license .

385 Table 1: Characteristics of the study participants at the time of sample collection, $\mathbf{n = 5 8 3}$

\begin{tabular}{ll}
\hline Characteristic & Values \\
\hline Age in year, Median (IQR) & $13(8,16)$ \\
\hline Age categories & \\
$0-2$ year & $41(7)$ \\
$3-12$ year & $240(41.2)$ \\
$13-18$ year & $302(51.8)$ \\
\hline Boys & $319(55.3)$ \\
\hline Symptomatic, $\mathrm{n}=554$ & $206(37.2)$ \\
\hline Hospitalized, $\mathrm{n}=501$ & $74(14.8)$ \\
\hline
\end{tabular}

Symptom profile, $n=74$

Fever

$42(60)$

Cough

$35(49.3)$

Runny Nose

$15(23.4)$

Sore Throat

$8(12.5)$

Body ache

Breathlessness

$4(6.3)$

Vomiting

$3(4.7)$

Fatigue

Eye pain

$1(1.6)$

\section{Centre wise samples}

Bowringand lady Curzon Medical College, Bangalore, Karnataka 203 (34.8)

Kasturba Hospital of Infectious diseases, Mumbai, Maharashtra

$69(11.8)$

Institute of Medical Sciences, Banaras Hindu University, Varanasi, $\quad 46$ (7.9)

Uttar Pradesh

National Institute of Virology, Bangalore Unit

Gandhi Hospital, Secunderabad, Telangana

$36(6.2)$

Postgraduate Institute of Medical Education \&Research, Chandigarh 36 (6.2) 
All India Institute of Medical Sciences, Jodhpur, Rajasthan

Christian Medical College, Ludhiana, Punjab

King George Medical University, Lucknow, Uttar Pradesh

Gandhi Medical College, Bhopal, Madhya Pradesh

Government Institute of Medical Sciences, Noida, Uttar Pradesh

Sawai Man Singh Medical College, Jaipur, Rajasthan

Gulbarga Institute of Medical Sciences, Gulbarga, Karnataka

Smt. NHL Muncipal Medical College, Ahmedabad, Gujarat

${ }^{1}$ Values are expresses as n (\%) unless specified.

Table $2 \mathrm{Ct}$ values among the study participants by grouping in different categories

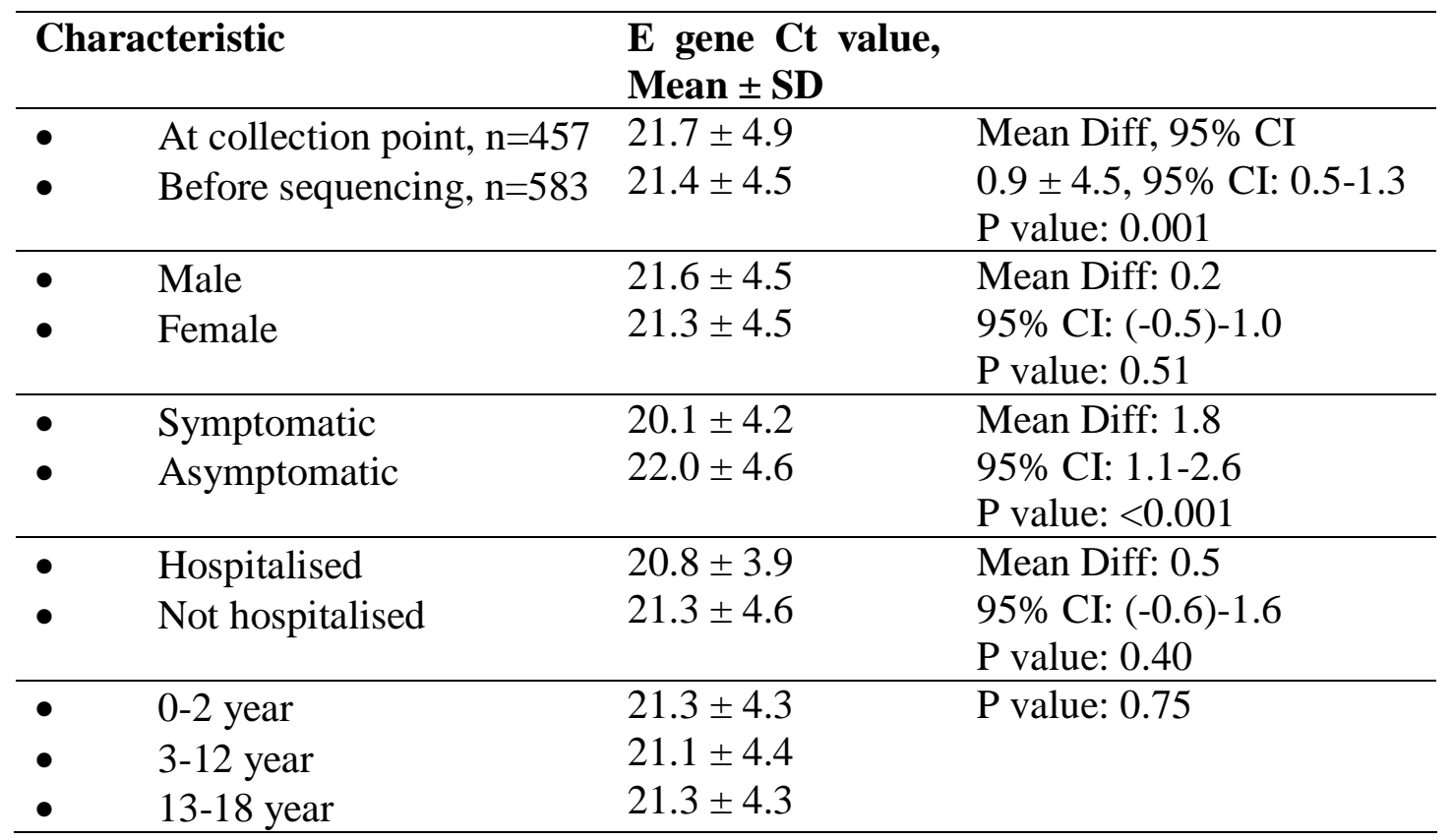

Supplementary Materials: The details of the percent genome coverage, relevant read mapped, the total reads and the EPI-Accession numbers for samples studied. 